\title{
Affirmative action, recognition, self-respect Axel Honneth and the phenomenological deficit of critical theory
}

\author{
Ação afirmativa, reconhecimento, autorrespeito \\ Axel Honneth e o déficit fenomenológico da teoria crítica
}

Nythamar de Oliveira*

\begin{abstract}
While liberal, redistributive views seek to correct and compensate for past injustices, by resorting to compensatory, procedural arguments for corrective justice, the recognition-based, communitarian arguments tend to promote by means of social movements and struggles for recognition a society free from prejudice and disrespect. In developing democratic societies such as Brazil, Axel Honneth's contribution to the ongoing debates on Affirmative Action has been evoked, confirming that the dialectics of recognition does not merely seek a theoretical solution to the structural and economic inequalities that constitute some of their worst social pathologies, but allows for practices of self-respect and subjectivation that defy all technologies of social control, as pointed out in Foucault's critique of power. The phenomenological deficit of critical theory consists thus in recasting the critique of power with a view to unveiling lifeworldly practices that resist systemic domination.
\end{abstract}

Keywords: Affirmative action; Critical theory; Lifeworld; Recognition; Self-respect; Social technologies

Resumo: Enquanto concepções liberais redistributivas buscam corrigir e compensar as injustiças do passado, recorrendo a argumentos procedimentais reparativos em favor da justiça corretiva, os argumentos comunitaristas embasados no reconhecimento tendem a promover por meio de movimentos e lutas sociais pelo reconhecimento uma sociedade livre de preconceitos e desrespeito. Em sociedades democráticas em desenvolvimento, como o Brasil, a contribuição de Axel Honneth para os debates em curso sobre a Ação Afirmativa tem sido evocada, confirmando que a dialética do reconhecimento não se limita a procurar uma solução teórica para as desigualdades estruturais e econômicas

* Associate Professor, Pontifical Catholic University of Rio Grande do Sul, Porto Alegre, RS, Brazil.<nythamar@yahoo.com> A preliminary draft of this paper was presented at the international colloquium on "Inequalities in the World System: Political Science, Philosophy, Law", held at Cebrap, São Paulo, on September 3-6, 2009. I am grateful to Marcos Nobre, Klaus-Gerd Giesen, Derrick Darby, Fouad Kalouche, and Yohan Ariffin for their critical remarks.

\begin{tabular}{|l|l|l|l|l|l|}
\hline Civitas & Porto Alegre & v. 9 & n. 3 & p. 369-385 & set.-dez. 2009 \\
\hline
\end{tabular}


que constituem algumas das suas mais graves patologias sociais, mas permite que as práticas de autorrespeito e de subjetivação desafiem todas as tecnologias de controle social, como apontado na crítica do poder de Foucault. O déficit fenomenológico da teoria crítica consiste, portanto, em reformular a crítica do poder com o intuito de desvelar as práticas do mundo da vida que resistem à dominação sistêmica.

Palavras-chave: Ação afirmativa; Autorrespeito; Mundo da vida; Reconhecimento; Tecnologias sociais; Teoria crítica

From the standpoint of what Foucault called "biopolitics" (1991, 1997; Honneth, 1991, p. 169), affirmative action (AA) may be fairly defined as an institutional technology of social control that seeks to rectify past injustice and to obtain a situation closer to an ideal of equal opportunity by policies aimed at a historically, socio-politically non-dominant group (typically, minority groups and women of all races), especially intended to promote fair access to education or employment. For the sake of elucidating the normative claims of this paper, I shall confine myself to the usage of AA as it seeks to rectify racial inequalities in Brazil, particularly in educational policies, even though I believe that similar arguments might be offered to make a case against gender and other social, economic inequalities as well. I am thus confined to a social philosophical approach to the problem of normativity in liberal, egalitarian policymaking, as I assume from the outset that public policies refer to decisionmaking processes that involve not only governmental power (esp. legislators and judicial decisions) but also civil society institutions broadly conceived, so as to comprise the public sphere, public opinion, social movements, trade unions, voluntary associations, NGOs, and numerous activities of individuals and interest groups. Since I am particularly interested in the social ethos and lifeworldly relationships in a given democratic political culture, I am assuming that the lifeworld (Lebenswelt) stands overall for the horizon of socially, culturally sedimented linguistic meanings that make up the background environment of competences, practices, and attitudes shared by social actors (Habermas, 1989, p. 119ss.) A phenomenological sociology of the lifeworld, in light of Alfred Schutz's analysis of everyday practices, has proved indeed relevant to the Brazilian sociocultural context as shown by Hermilio Santos's highly original study, "Interpretations of everyday life: approximations to the analysis of lifeworld" (Santos, 2009). The problematic relationship between systems and lifeworld lies, therefore, at the bottom of the normative grounds of social criticism, just as the basic ideas of cooperation and competition have determined social philosophical approaches to political theory. Following 
Habermas and Honneth's criticisms of systemic power, I propose to recast $\mathrm{AA}$ as a systemic technique of intersubjective recognition and redistributive justice which cannot ultimately be separated from its correlated lifeworldly techniques of self-esteem, self-care, and self-understanding. My contention here is that Honneth's theory of recognition successfully revisits Habermas's critique of Foucault's genealogy of power so as to address what I have dubbed "the phenomenological deficit of critical theory" (das phänomenologische Defizit der Kritischen Theorie), inherent in the Frankfurt School's attempt at a dialectic of enlightenment that breaks away from the demonization of the technological, instrumental domination of nature. An upshot of such a selfunderstanding of our modern condition is that the globalized, transnational phenomenon of juridification (Verrechtlichung) turns out to be an interesting instance of systemic-lifeworldly technologies that resist demonization as they contribute to accounting for the normative grounds of a critical theory of society at the same time that they function as efficient procedures of "reflective equilibrium" (in Rawlsian terminology) or as dispositifs, in the Foucaultian sense of technologies of power, at once reifying and breaking through a "linguistically generated intersubjectivity". (Habermas, 1997, p. 297) Axel Honneth's critique of the sociological and normative deficits of critical theory has been decisive for a more engaged, down-to-earth commitment towards the implementation of the very egalitarian, liberal, and communitarian ideals of self-respect, freedom, justice, and solidarity that such different authors as Rawls, Habermas, Foucault, and Fraser have stood for, even though stemming from somewhat opposing standpoints. Honneth's recasting of Foucault's power struggles for self-recognition (variously formulated as techniques of self-control, social and moral technologies) makes furthermore self-identity possible through the three forms of self-confidence, self-respect, and self-esteem in an intersubjective account of recognition (Honneth, 1996, chapter 5).

Much of what has been published and discussed about affirmative action is based upon personal opinions, feelings, and myths relating to ethnicity, gender, class, and other social constructs. When dealing with the social policies of AA we are often thinking of overcoming different forms of social prejudice, mostly unconscious or subtly embedded in our lifeworld. In itself, the act of discriminating is an epistemic category meant to differentiate, to discern, to judge how one thing differs from another on the basis of some rational criterion. Now, prejudice may be defined as a discrimination based on irrelevant grounds (social, racial or sexual). In conceptual terms, identity and difference are to be articulated in social ontological categories such as 
egalitarianism and diversity. As it will be argued towards the end of this paper, I think that ontological commitments in social philosophy cannot be ultimately separated from the correlated conceptions of subjectivity and language. According to Mosley, AA arguments must thus focus on the attempt to render the semantic fields of "race" or "gender" relevant to basic opportunities. Such arguments tend to be utilitarian, as they refer to distributive justice, minimizing subordination and maximizing social utility (Mosley; Capaldi, 1997, p. 53). For Pojman, we must attend to the difference between Weak Affirmative Action and Strong Affirmative Action: the latter is defined as preferential treatment, discriminating in favor of members of underrepresented groups (often treated unjustly or marginalized in the past), while the former simply seeks to promote equal opportunity to the goods and offices of a society. According to Pojman, since two wrongs don't make a right, he concludes that Strong Affirmative Action is both racist and sexist, and defends Weak Affirmative Action to encourage minorities to strive for excellence in all areas of life (esp. education, public offices, employment), so as to avoid reverse discrimination (Shaw, 1998). Some of the most known AA policies are: preferential hiring, nontraditional casting, quotas, minority scholarships, equal opportunities for underrepresented groups, and even "reverse discrimination", depending on the semantic, social context. This is certainly a rather simplified account of a complex issue, which I only evoke here in order to explore the social philosophical implications of policymaking procedures, as they were initially implemented in the US, especially against the background of the publication of Rawls's A theory of justice in 1971. We may think of seminal papers by Thomas Nagel and Judith Jarvis Thomson in 1973, as the ongoing debates in the United States supporting and opposing affirmative action have shown the highly complex problem of social integration in a pluralist democracy that takes diversity seriously. According to recent research at Yale University, the largest beneficiaries of affirmative action to date in the US are Caucasian women, although white males may as well be said to have benefitted through bailouts, draft deferments, legacy admission into top universities, etc. At any rate, both backward-looking and forward-looking justifications of affirmative action, whether they tend to be more or less deontological or utilitarian, seem to require some substantive approach to racial and cultural identity, as shown by different arguments developed by moral thinkers such as Albert Mosley, Louis Pojman, and Robert Fullinwider (Cohen et al., 1977). The classical opposition of US conservative and "liberal" positions respectively against and for AA eventually gave way to a liberal-communitarian debate, following different receptions of Rawls, Habermas, and Honneth's works on justice, inclusion, and recognition. 
While liberal, redistributive views seek to correct and compensate for past injustice, by resorting to compensatory procedural, arguments for corrective justice, the recognition-based, communitarian arguments tend to promote by means of social movements and struggles for recognition a society free from prejudice and disrespect (Fraser; Honneth, 2003). In developing democratic societies such as Brazil, Axel Honneth's contribution to this debate has been evoked, as over against Nancy Fraser's redistributive account, just to confirm that the dialectics of recognition is far from accounting for the structural and economic inequalities that constitute some of the worst social pathologies, as shown in recent articles by Sérgio Costa, Paulo Neves, Celi Pinto, and Ricardo Mendonça. In order to go beyond the Fraser-Honneth debate, I have sought to revisit Honneth's critique of Foucault's genealogical account of power and of Habermas's communicative action, by recasting a lifeworldly, nonreifying conception of juridification that meets social movements and identity claims stemming from grassroots practices of recognition from below. In effect, Honneth's dialectics of recognition could offer us a much more defensible diagnosis of the Brazilian symbiosis between a slave-societal ethos, an ideology of racial democracy, and a lifeworldly praxis of racial disrespect as his "critique of power" reexamines the Foucaultian, Habermasian accounts of systemic power relations. Precisely because racial inequalities and ongoing discussions on AA social policies cannot be reduced to racialized, ideological discourses, the complex problem of intersubjective and hybrid accounts of self-identity, cultural identity, miscegenation, and social constructs such as race and gender must not be dismissed as too eclectic or too subjective, as critics of postmodernist and postcolonial studies seem to purport.

Like most representatives of "liberal" and conservative standpoints, Mosley and Pojman had clearly different ideas about how to make things more equal for all. The main difference seems to consist in that Mosley doesn't think equality means simply treating everyone equally, whereas Pojman takes equal treatment for an end result that would eliminate unjust discrimination. The term "reverse discrimination" has been used throughout most texts. The purpose of affirmative action is to open a door that was once closed. It allows people who are qualified to walk through. It increases competition from a world of work that was once white, male, heterosexual, abled bodied etc. to one that includes all people. In the US, we are often reminded that affirmative action even works for veterans! In Brazil, AA policies mainly refer to systems of preferred admissions (quotas) for racial minorities (blacks and native Brazilians), the poor and people with disabilities, and they have also been regarded as supplementing other programs of social inclusion such 
as conditional cash transfer and similar welfare programs. One must not overlook that there are already quotas of up to $20 \%$ of vacancies reserved for the disabled in the civil public services. In the United States, access to the American Dream is often framed as a fair race in which the swiftest runners win. Critics say we should eliminate affirmative action because it gives some runners an unfair head start in an otherwise fair race. At the same time, many supporters of affirmative action say it is essential because some competitors are disabled and need a head start in order to compete in the race. But what if both of these perspectives miss the point about affirmative action? From this perspective, we can see that policies that promote inclusion, like affirmative action, are designed to equalize the conditions of a previously unfair race. Hence the emphasis on the Rawlsian principle of "fair equality of opportunities", combined with the basic principle of "equal liberty": just as one cannot promote universalizable ideals of justice and freedom without egalitarianism, one cannot celebrate diversity and the principle of difference (in its various social, egalitarian versions) without presupposing the fair equality of opportunities for all parties. The intuitive idea here is that all primary goods (liberty and opportunity, income and wealth, the bases of self-respect) are to be distributed equally unless an unequal distribution of any of these goods is to the advantage of the less favored (Rawls, 1971). We all know that there are numerous obstacles that litter the lanes of disadvantaged runners: historically, nonwhites have found their path blocked by racial discrimination; poverty creates broken lanes filled with potholes and other dangers; women find their lanes filled with impenetrable barriers; and urban youth are derailed far from the finish line by the school-to-prison pipeline. Meanwhile, those runners who aren't kept back by race, class, or gender discrimination are privileged to run a race in which their ability to compete is not impeded by unwarranted arbitrary barriers. Some runners are luckier still. They are benefited by a host of privileges such as family connections, wealth, and an array of other factors that deliver them to the finish line ahead of all the other runners without even to have to break a sweat. Their lane is, in effect, a people-mover, an electrically powered lane that moves them along even when they simply assume the position of a runner while never having to actually lift a foot to propel themselves forward. To be sure, it is difficult for anyone to know what it feels like to be discriminated against unless it has happened to them. And yet, as Rawls himself suggested, one doesn't have to be black, a woman, Jewish or gay to take a radical stand against racism, phallocentrism, anti-semitism or homophobia. The point here is that this is exactly why nobody should ever have to be the victim of unjust and immoral discrimination. All people 
should be treated equally with respect and given fair opportunity to flourish as human beings. People can thus respect each other's differences and mutually recognize themselves as individuals and as members of distinct social, interest groups. Honneth's conception of intersubjective recognition seeks precisely to move beyond the individualist, atomistic foundation for sociality and recast Habermas's conception of individual self-formation through socialization by correcting some of the problems in the latter's lifeworld-system divide.

Gilberto Freyre's 1933 seminal book Casa-Grande e Senzala (2006) see ET: The Masters and the Slaves - has been hailed as the most representative work on Brazilian identity ever, opening up endless debates on collective selfesteem, self-understanding, and race relations in Brazil, esp. racial mixture, the quasi-romantic idealization of the mulatto (pardo, moreno), and the so-called myth of racial democracy - even though there is no occurrence of the term in this book. Beyond its immediate context of the contemporaneous discussion on regionalism versus universalism following the Modern Art Week in 1922, Freyre's analyses contributed to new, comparative readings of slavery systems and racism in the Americas. One particular upshot of the racial democracy myth is the ideology of whitening and the concomitant practice of miscegenation or race mixture, described by many scholars as the primary pillar of white supremacy in Latin America, particularly in Brazil (Twine, 1997, p. 87). According to Twine, the whitening ideology "was originally coined by the Brazilian elite to reconcile theories of scientific racism with the reality of the predominantly nonwhite population of their country" toward the turn of the 19th century. Thus Afro-Brazilian children are systematically disempowered as they learn not to talk about racism, regarded as a taboo subject for discussion with their parents and peers (Twine, 1997, p. 153). It was such a perverse circle that racial democracy has been fueling for decades throughout generations and it was only recently, especially after the end of military dictatorship in Brazil, that middle-class and the average citizen began talking about these social pathologies. Brazilian citizens have certainly been socialized into a racist, paternalist political culture, so full of contradictions and shortcomings when compared to the normative, regulative ideals of the democratic, egalitarian yardstick. And yet, this making of a political culture is only sustained to the extent that Brazilians also produce and reproduce such a culture. The shift from a hypocritical racial democracy towards a truly pluralist democracy has in effect been the only way out of the elitist pseudoliberalism of both military and civilian calls to "modernize" Brazil. Just as the aestheticist regionalism and nationalism of the modernist movement of the 1920s gave way to a technocratic, nationalist modernization in the 1950s and 1960s only 
to highlight the oligarchic, hierarchical relations of power that made Brazil one of the most socially unequal nations of the planet, a moral revolution from below alone can secure the rule of law for all and call for a public, democratic distribution of primary goods. If Brazil remains too far from a well ordered society and public participation in the bargain processes is still remote from vast, excluded segments of the population, the political thrust of social movements meets a fortiori the normative criteria of a concept of democracy that defies and transgresses any corrupted, systemic "power that be" for the sake of the people. The egalitarian premises in AA procedures can do precisely that, whenever one has to be reminded that the outcast in Brazil discover their own identity as citizens, rights-bearers or as end-in-themselves only when they become visible in the public sphere and get talked about in the media. Hence a radical critique of state and society is not necessarily opposed to the regulative ideals of a procedural theory of justice. In his highly original account of racial problems in Brazil, Costa has taken a critical stand against modernist, teleological accounts of racism such as those inspired by Habermas, Beck and Giddens's analyses of social pathologies, to a great extent because of the limitations of importing European patterns of modernity and identity to the Brazilian context. On the other hand, however, even though he praises postcolonial studies for being particularly useful for his own refusal to import US, binary categories of anti-racism, Costa remains skeptical about the normative deficit of Brazilian sociological contributions to this ongoing debate (Costa, 2006). In another assessment of the same problem, Costa argues that the category of race, once transformed into a tool for social analysis and normative desideratum, leads to an incomplete, biased understanding of the Brazilian makeup, an objectifying view of social relations and eventually to a reduction of social identities to their political, instrumental dimension (Costa, 2002). In order to tackle the problem of racial identity in Brazil, Mendonça recasts Habermas's discourse, communicative theory to arbitrate between Honneth's self-realization and Fraser's parity of participation guiding ideas: if it is only through interactive participation that self-realization can be ultimately thought in moral terms, one must inevitably resort to a sound socialization so that individuals are empowered to affirm themselves as social actors and take part in the effective construction of a just society, by means of free exchanges and interplays of revisable validity claims (Mendonça, 2007). A similar argument of complementarity is offered by Pinto, albeit from a different programmatic platform. According to Pinto, distribution cannot be reduced to recognition, as this would render the question of justice void. Recognition is, moreover, a highly polysemous word and its reduction to an exclusive definition evacuates 
both its heuristic value for social theory and its potential for struggles for justice. Recognition qua self-recognition (self-esteem, in Honneth) and qua status (in Fraser) are not mutually exclusive, but are different moments of the same process of theoretical elaboration and political struggle, and might be regarded in many circumstances as complementary notions. Recognition as public policy and as state policy are not contingent upon the self-recognition of individual subjects, but are limited to a specific range of "remedies", to employ Fraser's terminology. On the other hand, according to Pinto, recognition as self-recognition is essential to the construction of the subject of action in social struggles. There are only "dominated" insofar as they recognize themselves as such in their struggles against "domination". There is no such a thing as feminism before the emergence of the feminist, just as there is no parity of participation prior to the self-recognized subject as an equal. Finally, both in Fraser and in Honneth, the moments of construction of situations of disrespect are absent, just as the shift from nonrecognition and misrecognition to recognition, which renders the scope of both theories quite narrow (Pinto, 2008). In the last analysis, the problem is whether recognition can actually function as some form of moral principle, as Honneth claims, even if he does not assume it to be taken for a foundational or unifying principle (systematically conceived, not necessarily as in a metaphysical system, since Honneth's critical reading of Hegel is clearly postmetaphysical). Honneth has in effect set up an interdisciplinary research program that accounts both for a theory of justice and for a theory of democracy: recognition is what sets democracy in motion, making it both possible and desirable, as we are always caught up in ongoing struggles for recognition. We are thus led from a dialectical appropriation of Freyre's problematic account of racial relations and the social patterns of disrespect, misrecognition, and recognition towards social policies meant to promote self-realization through the self-assertion and self-understanding of Afro-Brazilians' social struggles and their normative claims raised in these struggles. It seems that Honneth's theory of recognition becomes even more relevant for AA social policies when it is recast in light of its point of departure vis à vis Habermas's critique of Foucault's systemic techniques of power.

In his Critique of power, Honneth sets out to show "that Adorno must have failed in the task of an analysis of society, since throughout his life he remained imprisoned to a totalized model of the domination of nature and was thus unable to comprehend the 'social' in societies" (1991, p. xii). Honneth regarded the Dialektik der Aufklärung as one of the most representative works for a critical self-understanding of the 20th-century Zeitgeist, its lifeworldly 
disenchantments, and social pathologies. But it is only by alluding to both Foucault and Habermas, that Honneth seeks to move beyond this modern predicament, as they propose post-Hegelian, alternative accounts in their respective opposing views of power. While Foucault rehabilitates an "actiontheoretic paradigm of struggle", Habermas calls for a paradigm of "mutual understanding". Both models can be thus regarded as alternative accounts to the sociological deficits of critical theory and earlier phenomenology. My working hypothesis here is that Honneth's indebtedness to Habermas and Foucault betrays, furthermore, the other two Hs - Husserl and Heidegger-which, together with Hegel, were so decisive for the phenomenological emergence of intersubjective themes such as recognition, liberation, and alterity in postwar France. According to Honneth (1996, p. 156), the kernel of Sartre's social philosophy is that "social conflicts are to be understood, above all, as disruptions in the relationships of recognition between collective actors". Sartre saw thus anti-semitism as a form of social disrespect as he shifts away from the reciprocal reification of the ontological dualism between the en-soi and the pour-soi of his earlier phenomenological account of otherness in L'être et le néant. Granted, Sartre's indebtedness to the Hegelian conception of intersubjectivity took him farther beyond Husserl's solipsistic account of consciousness and Heidegger's self-deceptive conception of Dasein, so that his recasting of the three Hs (Hegel, Husserl, Heidegger) paved the way for his later critique of colonialism and his Marxist, liberationist theory of recognition inherent in his praise of négritude. As early as 1956, Sartre denounced "colonialism [as] a system that infects us with its racism" (Sartre, 1956). Honneth follows Habermas when the latter argues that Sartre's moral decisionism, like Heidegger's and Foucault's, cannot account for the normative thrust needed to carry out emancipatory struggles for recognition, even though his unmasking of imperialism and colonial power pointed to the crisis of Cold War capitalism (Honneth, 1996, p. 159). Habermas's own theory of communicative action sought to overcome the late capitalist crisis of legitimation, without falling back in the aporias of a critique of ideology and philosophies of consciousness, on the one hand, and avoiding the pitfalls of relativism, skepticism and historicism, on the other, resulting from postmodern criticisms of modernity. Habermas reclaims thus the Kantian legacy of a normative foundation for the political sphere, at the same time that he maintains the separation of morality and legality, and the primacy of a communicative normativity regulated by rational discourse, shared by all and capable of guiding human action in democratic, pluralist societies. Political questions are to be debated, therefore, within the context of a discourse ethics, founded in the form of an argumentative, moral logic, 
hence both normative and universalizable. The Habermasian theory succeeds in articulating the question of normativity with the political, social question of institutionalization, in the very conception of an integrated model which differentiates the systemic world of institutions (defined by their capacity of responding to the functional demands imposed by the environment /context) from the lifeworld (Lebenswelt, i.e. forms of cultural, societal, and interpersonal reproduction that are integrated through the norms consensually accepted by all participants in the social world). And yet, insofar as it is conceived both as the precondition and starting point for a process of systemic differentiation and as the threatened pole of systemic imperatives leading to the colonization of the lifeworld, modern rationalization seems to fall prey to an inevitable paradox, as Habermas himself pointed out in his meticulous analyses of lifeworld and system (1989). While the rationalization of the Lebenswelt renders possible the differentiation of autonomous subsystems, opening thus the utopian horizon of a civil society in which the spheres of action formally organized constitute the foundations of the post-traditional social world of human beings (private sphere) and citizens (public sphere), it seems to dig, however, its own grave in a technological society dominated by monetarization and bureaucratization. Habermas's own solution out of this impasse consists precisely in resorting to communicative reason, as opposed to instrumental, purpose-oriented rationality (Zweckrationalität), so as to avoid the reifying mechanisms of the coordination of actions, social integration, and symbolic reproduction. As Albrecht Wellmer remarked, Habermas in fact reformulated the same paradox of rationalization already at work in Weber, Adorno, and Horkheimer's critical analyses of capitalism, with the important proviso that the emergence of a post-traditional rationality in modern Europe allows for "different possible constellations concerning the relationship between system and lifeworld" (Bernstein, 1985, p. 57). Nevertheless, it seems that we can hardly move beyond this paradoxical, vicious circle every time we revisit the problem of normativity at stake. If on the one hand, we cannot simply square normativity with the lifeworld, as opposed to the technization of cognitive and practical relationships and the instrumental dealings of differentiated institutional systems, the paradox will simply persist, on the other hand, within any attempt at coordinating a supposedly democratic "consensual action". Hence, just as Habermas saw the same problem inherent in Rawls's contractarian "original position", Wellmer spots here the impossibility of defeating a self-vindicating rationality, whose practical intent is anchored in lifeworldly, tacit assumptions, posited with the avoidance of performative contradictions every time one has to come across in everyday talks and dealings. The ideal speech situation 
functions thus like the "grammaticalness we have for the sentences of our native language" (Rawls, 1999, p. 41) - we do not even care to think about it, but it has been always already presupposed by all speakers. To be sure, as Wellmer remarked, idealized lifeworlds might strike us as nonsense or undesirable chimeras but, like Rawls's procedural devices of the well-ordered society and reflective equilibrium, they might help us in thought experiments that call into question our intuitive, taken-for-granted notions of equality and freedom. In effect, both Rawls and Habermas follow Kant's procedural wager that no rational means-ends system can defy the irreducibility of human means to their ultimate, universalizable ends, since human dignity or humanity is to be regarded as an ultimate end in itself (Endzweck). In one of Habermas's earliest reflections on the relationship between technology, science, and the lifeworld in the 60 s we read:

I should like to reformulate this problem with reference to political decision-making. In what follows we shall understand 'technology' to mean scientifically rationalized control of objectified processes. It refers to the system in which research and technology are coupled with feedback from the economy and administration. We shall understand 'democracy' to mean the institutionally secured forms of general and public communication that deal with the practical question of how [humans] can and want to live under the objective conditions of their ever-expanding power of control. Our problem can then be stated as one of the relation between technology and democracy: how can the power of technical control be brought within the range of the consensus of acting and transacting citizens? (Habermas, 1970, p. 57).

Like Rawls and Honneth, Habermas refuses to reduce the social construction of rule-following procedures to a rational choice theory or utilitarian calculus, just as they all resist a decisionist condemnation of the technological society and its self-regulating institutions as one finds, say, in Martin Heidegger and Jacques Ellul. Like revisited versions of the Pascalian wager, Habermas's modernist creed constantly seeks to render its premises reasonably credible, as his ethical universalism engages in endless battles with infidels and believers from every hill. As one of his most sympathetic interlocutors remarked,

Can we still, in our time, provide a rational justification for universal normative standards? Or are we faced with relativism, decisionism, or emotivism which hold that ultimate norms are arbitrary and beyond rational warrantability? These became primary questions for Habermas. The fate - indeed, the very possibility - of human emancipation depends on giving an affirmative answer to the first question and a negative answer to the second (Bernstein, 1985, p. xv). 
It seems to be fair enough to gather that Habermas has sought to rescue the normative grounds of modern liberal democracies, against the diversity of communicative, lifeworldly backgrounds, without falling back into some form of absolutism (as one finds in religious and metaphysical models) or succumbing to relativism, nihilism or historicism (as Heidegger, Foucault, and postmodernists do, according to Habermas). Hence, the technological modern predicament is not so much how to make a good use of natural and social resources (as if we could simply use those things like tools) but rather how to deal responsibly and democratically with the uncoupling of systems and lifeworlds, as the latter cannot be reduced to the former. Habermas's own proposal out of the pickle is to recast the normative thrust of democracy in critical-theoretical terms, so that the satisfaction of functional needs of action systematically integrated must find its limits in the integrity of the lifeworld, i.e. in the very demands of the spheres of action which are socially, communicatively integrated (Habermas, 1984, p. 307). Although I cannot elaborate on this question here, it is my contention that Sandel's criticisms addressed to Rawls's liberalism may as well be applied to the Habermasian attempt to articulate a Kantian proceduralism with a Hegelian-inspired view of ethical life (Sittlichkeit). Honneth's critique of Habermas's dualistic conception of society aims precisely at this, which might be perceived as a systemic flaw: one must go back to substantive conceptions of the good in order to account for the best procedures, even with a view to repairing injustice (Honneth, 1991, p. 221). Honneth addresses Habermas's immanent critique as still indebted to a "philosophy of history influenced by Heideggerian Marxism", so as to unmask the anthropological blindspots of his confusing accounts of systemic and lifeworldly fictions. Indeed, a similar problem lies at Habermas's procedural formulation of the ideal speech situation, which can be solved with the support of an analysis of civil society's voluntary associations that secure democratic values against the state and economic colonizations of the lifeworld. In his later formulation of his procedural model of deliberative, participatory democracy in Faktizität und Geltung (Between Facts and Norms), Habermas contends that his theory of communicative action stands as a third way between a systemictheoretical sociology of law (such as the one advocated by Niklas Luhmann) and a liberal, universalist theory of justice (such as John Rawls's). After having developed a theory of justice in vacuo, says Habermas, Rawls recasts the "old problem of how the rational project of a just society, in abstract contrast to an obtuse reality, can be realized after confidence in the dialectic of reason and revolution, played out by Hegel and Marx as a philosophy of history, has been exhausted - and only the reformist path of trial and error remains both 
practically available and morally reasonable" (Habermas, 1998, p. 57). For Habermas, Rawls's problem appears as "the return of a repressed problem", insofar as it recasts the modern model of natural law (social contract) in procedural terms (original position). Nevertheless, as Dick Bernstein put it so well, we end up with an epistemic justification paradox of self-referentiality at the very uncoupling of systems and lifeworld:

[Habermas] wants to do justice to the integrity of the lifeworld and social systems, and to show how each presupposes the other. We cannot understand the character of the lifeworld unless we understand the social systems that shape it, and we cannot understand social systems unless we see how they arise out of activities of social agents. The synthesis of system and lifeworld orientations is integrated with Habermas's delineation of different forms of rationality and rationalization: systems rationality is a type of purposive-rational rationality, lifeworld rationality is communicative rationality (Bernstein, 1985, p. 20).

Along the same lines and reminiscent of Honneth's own assessment, James Bohman has remarked that "Habermas's criticism of modern societies turns on the explanation of the relationship between two very different theoretical terms: a micro-theory of rationality based on communicative coordination and a macro-theory of the systemic integration of modern societies in such mechanisms as the market" (Habermas, 1997). To be sure, there is no clear-cut separation of lifeworld and systems rationalities, since it is precisely because of the systemic colonization of the lifeworld that social actors can have more and more access to its general structures and are urged to seek integration amid all complex differentiations, with a view to attaining emancipation and understanding. Hence, to the structural differentiation of the lifeworld in its social integration, cultural reproduction and personal socialization, there must be an interactive differentiation of the systemic institutions steered by money and power (economy and bureaucratic administration). What is at stake, after all, is the institutionalization of the social world, beyond traditional accounts of society and state. Honneth has convincingly shown, however, the impossibility of maintaining communicative reason immune from the instrumentalization of social action in the very attempt to tackle the paradox of the rationalization of lifeworldly relations, as anticipated by Habermas's own account of socialization. In this sense, it seems that one is condemned to the Foucaultian predicament of social technologies, at once systemic and lifeworldly, as the reification implicit in the very interplay of recognition and disrespect seems to provide us with a good phenomenological clue to the correlation between a social ontology, moral grammar, and accounts 
of intersubjectivity. By effecting a rapprochement between the procedural conceptions of a reflective equilibrium (Rawls) and the lifeworld (Habermas) we can thus reenact, as it were, a hermeneutics of normativity correlated to the facticity of a democratic ethos inherent in a pluralist, political culture, capable of integrating systemic and pragmatic aspects of a diversity of practices and codifications (modus vivendi) that subscribe to an overlapping consensus, especially when dealing with universalizable claims and local action practices, such as human rights and public policies, among which AA procedures stand out as reifying and demythologizing remedies. Social philosophy can be thus recast as a correlate of a philosophy of nature that allows for sustainable technologies that effect the return of ecological themes such as home, earth, and global dwelling without romanticism or the nostalgia for a primordial reconciliation of technique and nature. Even though I won't be able to elaborate on these developments in this paper, it is my contention that Foucault's critique of a neoliberal "technological society" (to paraphrase Ellul) cannot be dismissed as a nihilistic, postmodernist threat to the unfinished project of emancipatory democratization -as Habermas insinuated in his Philosophical Discourse of Modernity - but may as well be integrated into a sustainable critique of the modern pathologies of 21st-century capitalism. As Nancy Fraser rightly observed, we must draw an important distinction between Foucault's empirical insights and the normative problems inherent in his writings, as we distinguish, say, Foucault's genealogical analyses of the state qua "technology of government" from the normative thrust of "new modes of governmentality" in postnational configurations of "neoliberal globalization" (Fraser, 2008). Social technologies such as AA procedures are, therefore, revealing for the "ontological history of ourselves", bringing together interplays of knowledge and power, intersubjective and reflective accounts of self-understanding. Following Honneth's recasting of the critique of power, the phenomenological deficit of critical theory ultimately unveils communicative networks and lifeworldly practices that resist systemic domination. Thus technologies of power and techniques of the self are brought together so as to make sense of the correlation between discursive and nondiscursive practices, epistemai and dispositifs, knowledge and power relations in the intricate networks of socialization, individualization, and normalization that make up subjectivation (Foucault, 2001. As Foucault himself remarked,

I think that if one wants to analyze the genealogy of the subject in Western civilization, [s] he has to take into account not only techniques of domination but also techniques of the self. Let's say: [s] he has to take into account the interaction between those two 
types of techniques - techniques of domination and techniques of the self. [S] he has to take into account the points where the technologies of domination of individuals over one another have recourse to processes by which the individual acts upon [her]himself. And conversely, [s] he has to take into account the points where the techniques of the self are integrated into structures of coercion and domination. The contact point, where the individuals are driven by others is tied to the way they conduct themselves, is what we can call, I think government. Governing people, in the broad meaning of the word, governing people is not a way to force people to do what the governor wants; it is always a versatile equilibrium, with complementarity and conflicts between techniques which assure coercion and processes through which the self is constructed or modified by [her]himself (Foucault, 1991, p. 203-204).

\section{References}

BERNSTEIN, Richard J. Habermas and modernity. Cambridge: MIT Press, 1985.

COHEN, Marshall; NAGEL, Thomas; SCANLON, Thomas (Eds.). Equality and preferential treatment. Princeton: Princeton University Press, 1977.

COSTA, Sérgio. Dois atlânticos: teoria social, anti-racismo, cosmopolitismo. Belo Horizonte: Edufmg, 2006.

. A construção sociológica da raça no Brasil. Estudos Afro-Asiáticos, Rio de Janeiro, v. 24, p. 35-61, 2002.

FOUCAULT, Michel. Governmentality. In: BURCHELL, Graham; GORDON, Colin; MILLER, Peter Miller (Eds.). The Foucault Effect: Studies in governmentality. Harvester Wheatsheaf. Chicago: University of Chicago Press, 1991.

. About the beginning of the hermeneutics of the self, edited by Mark Blasius, Political Theory, Evanston, v. 21, n. 2, p. 198-227, May 1993.

. The birth of biopolitics. In: RABINOW, Paul (Ed.). Michel Foucault, Ethics: Subjectivity and truth. New York: The New Press, 1997.

. L'herméneutique du sujet. Paris: Seuil, Gallimard, 2001.

FRASER, Nancy; HONNETH, Axel. Redistribution or recognition? A politicalphilosophical exchange. London: Verso, 2003.

FRASER, Nancy. Scales of justice: Reimagining political space in a globalizing world. New York: Columbia University Press, 2008.

FREYRE, Gilberto. Casa-grande e senzala. Rio de Janeiro: Global Editora, 2006 (1933).

HABERMAS, Jürgen. The theory of communicative action I: Reason and the rationalization of society. Boston: Beacon Press, 1984.

. The theory of communicative action II: Lifeworld and system. Boston: Beacon Press, 1989. 
. The philosophical discourse of modernity. Boston: MIT Press, 1997.

. Between facts and norms. Cambridge: MIT Press, 1998.

. Toward a rational society. Boston: Beacon Press, 1970.

HONNETH, Axel. The critique of power: Reflective Stages in a Critical Social Theory. Cambridge: MIT Press, 1991.

. The struggle for recognition: The Moral Grammar of Social Conflict. Cambridge: MIT Press, 1996.

MENDONÇA, Ricardo. Reconhecimento em debate: os modelos de Honneth e Fraser em sua relação com o legado habermasiano. Revista de Sociologia e Política, Curitiba, v. 29, p. 169-185, 2007.

MOSLEY, Albert. Affirmative action: Pro. In: MOSLEY, Albert; CAPALDI, Nicholas (Eds.). Affirmative action: Social justice or unfair preference? London: Rowman \& Littlefield, 1997.

NEVES, Paulo. Luta anti-racista. Rbcs, São Paulo, v. 20, n. 59, p. 81-96, 2005.

PINTO, Celi. Nota sobre a controvérsia Fraser-Honneth informada pelo cenário brasileiro. Lua Nova, São Paulo, n. 74, p. 35-58, 2008.

POJMAN, Louis. The case against strong affirmative action. In: SHAW, William (Ed.). Personal and social morality (Ethics). 4th ed. Wadsworth Publishing Co., 1998.

RAWLS, John. A theory of justice. Cambridge: Harvard University Press, 1999 (1971).

SANTOS, Hermilio. Interpretations of everyday life approximations to the analysis of lifeworld. Civitas, Porto Alegre, v. 9, n. 1, p. 103-117, 2009.

SARTRE, Jean-Paul. Le colonialisme est un système. Les temps modernes, v. 126. 1956.

SHAW, William (Ed.). Personal and social morality (Ethics). 4. ed. Wadsworth Publishing Co., 1998.

THOMSON, Judith Jarvis. Preferential Hiring. In: COHEN, Marshall; NAGEL, Thomas; SCANLON, Thomas (Eds.). Equality and preferential treatment. Princeton: Princeton University Press, 1977.

TWINE, France Winddance. Racism in a racial democracy: The maintenance of white supremacy in Brazil. Piscataway: Rutgers University Press, 1997.

Recebido em: 22/09/2009

Aprovado em: 15/10/2009 